\title{
The literature review on changes in research trends regarding distance education before and during the COVID-19 pandemic (2017-2020)
}

\author{
Fadıl Şiraz* \\ *Uluönder Special Education and Application Center, Eskişehir, Turkey
}

\begin{abstract}
In the eary periods of distance education when it was considered as a separate field. During the pandemic process, even the education - training and evaluation processes have started to be done through distance education. The present research tries to reveal research trends including the development of distance education and the pandemic process. The research was carried out in qualitative research design with document analysis. 333 articles published in the field of distance education between 2017-2020 in the Dergipark database constitute the sample of the present research. These articles are examined in terms of form, methodology and content. Data analysis for the present research was conducted by descriptive analysis method. While the trend of quantitative research was at the forefront in the distance education researches until the pandemic process; in 2020, which covers the pandemic process, the qualitative research trend has come to the fore and the interviews were conducted from afar; there are also studies that try to reveal the problems related to distance education, and the use of online tools has increased. In addition, it has been observed that studies on distance education have started to be published in many other fields apart from the field of distance education.
\end{abstract}

Keywords: pandemic process, distance education, changes in distance education, research trends in distance education, changes in research trends in distance education.

\section{INTRODUCTION}

\section{An overview of Distance Education}

All kinds of developments in the world directly affect all aspects of education and training. In addition to science and technological developments, and beyond the information age and Industry 4.0 and before the discussions on the transition to Society 5.0, individuals are sometimes required to receive the education they desire or have to take from a distance. With the introduction of computers and the internet as a means in education and training, the conceptualization of computer-based learning, web-based learning, online learning,

\section{Components}

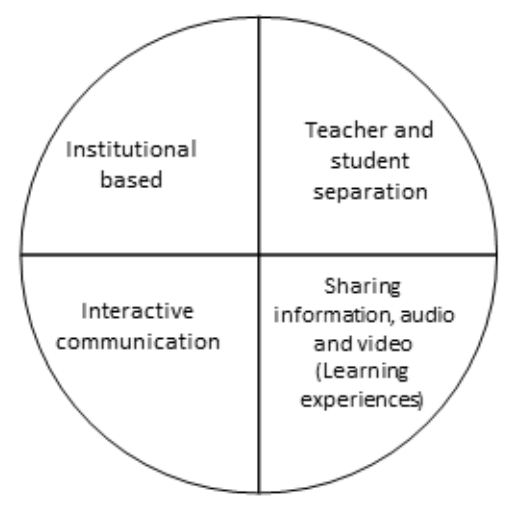

Figure 1: DE Components (Simonson \& Schlosser, 2009, p. 2) e-learning, open learning, blended learning, mixed learning, etc. seems to have been identified with the distance education (DE) in the related literature. The DE components identified by Simonson and Schlosser (2009) are presented in Figure 1.

\section{Distance Education in a Historical Perspective}

Taking DE in a historical perspective, it is stated that correspondence is divided into radio, television, internet and online periods in the international literature (Allen \& Seaman, 2011; Kenthor, 2015). Periods of DE are presented in Figure 2.

Although it was stated that the DE as a method was first used by Boston Newspaper in 1728, it is reported that the first institution (with correspondence) that started DE was Illinois Wesleyan College in 1873 and the first DE center was established at the University of Wisconsin in 1906

Corresponding Author e-mail: fadilsiraz@yahoo.comM https://orcid.org/0000-0002-5478-7529,

How to cite this article: Şiraz F, (2021). The literature review on changes in research trends regarding distance education before and during the COVID-19 pandemic (2017-2020). Pegem Journal of Education and Instruction, Vol. 11, No. 4, 2021, 82-99

Source of support: Nil

Conflict of interest: None.

DOI: 10.47750/pegegog.11.04.09

Received: 04.05.2021

Accepted: 10.07.2021 Publication: 01.10 .2021 


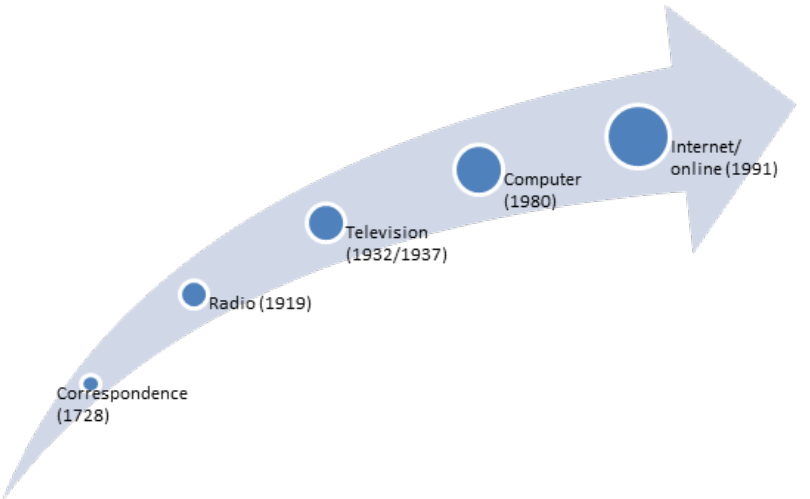

Figure 2. International Development Periods of DE

(Emmerson, 2004, p. 2; Kentnor, 2015). The use of radio in DE started at the University of Wisconsin in 1919; and the use of television started at the University of Iowa in 1932/1937 (Koening \& Hill, 1967; cited; Kentnor, 2015, p. 24-27). It is also stated that the DE system with correspondence started in 39 universities in the USA until the 1930s. The Distance Education and Training Council was established in 1955; and a new approach was taken in the field of DE with the Articulated Instructional Media Project at the University of Wisconsin in the 1960s. With this project, a new evaluation system was adopted in DE and also another important approach was the activation of ARPANET at Stanford University and UCLA at Utah University as a communication network project during the same years (Emmerson, 2004, p.3,10). The United Kingdom Open University was established in 1971 in Europe and similar institutes were opened in West Germany, Japan and Canada (Simonson \& Schlosser, 2009). The University of Alaska achieved the use of satellites in the field of DE with the Instructional Television Fixed Service (ITFS) in 1975 (Emmerson, 2004, p. 12). Although computers started to be used in DE in the 1980s, the use of the Internet in DE for online education started in Phoenix University in 1991 (Carlson \& Carnevale; cited in: Kentnor, 2015, p. 28).

\section{Distance Education process in Turkey}

With a historical perspective, the development process of DE in Turkey is presented by Isman (2005) in three periods: i) conceptualization, ii) education by mail, and iii) use of communication technologies. According to Bozkurt (2017), the periods of the DE in Turkey are conceptual (1923-1955); by mail (1956-1975); radio-television (1976-1995) and internetweb (1996 -...). The periods of DE in Turkey are presented in Figure 3.

Isman bases conceptualization period in Turkey on the 1924 Teacher Education Report by J. Dewey and states that Dewey mentioned about education through communication, but this could not be realized due to the conditions of that day. Kaya (2002) reported that the historical process of DE in Turkey

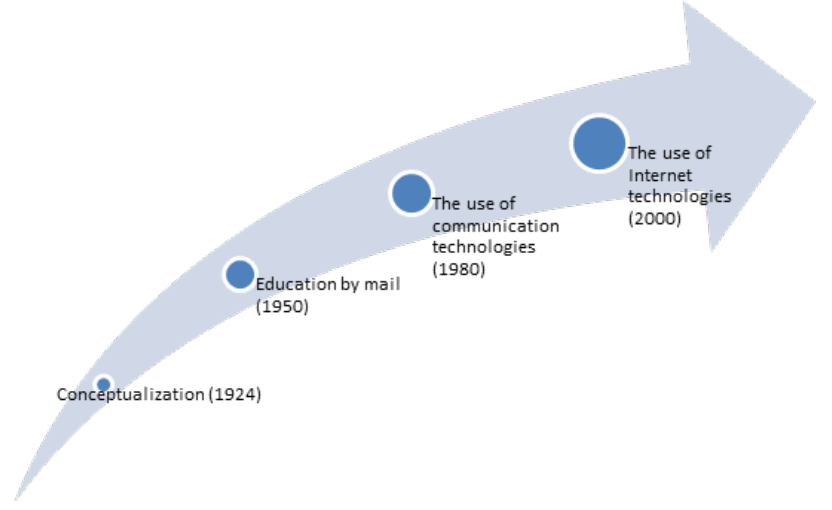

Figure3. Development Periods of DE in Turkey

was initiated in the Faculty of Law of Ankara University by mail in the 1950s; and in the 1960s, DE by mail increased in higher education by the same means. In addition, Isman (2005) states that the DE process started in 1961 under the leadership of the Ministry of National Education and the Mail Teaching Center was established. In 1983, Anadolu University Open Education Faculty was opened in accordance with the Higher Education Law numbered 2547, with which the Higher Education Center by Mail was established in 1974. Broadcasting to support open education with television started in the 1980s, and the open education high school affiliated to the Ministry of National Education was opened in 1992 and open primary education in 1998. The use of internet technologies in the field of DE started in the 2000s; and first online master's programs started at Bilgi University in 2000 and the doctoral programs at the Middle East Technical University in 2001 (Bozkurt, 2017; Kaya, 2002).

\section{Distance Education today}

After discussing the DE field theoretically until Covid-19, the effect of the pandemic process on education and its reflections in the field of DE should be examined. While the distance between humans has increased during the pandemic process; the distance between humans and digital environment is decreasing. In this process, the dimension of education all over the world is undergoing a rapid change. Educators and students benefit from the digital environment to complete the education and training process (Debeş, 2021). It is also emphasized that the first period in the field of DE will be completed with equality in access and that the issues of cyberization of education, transmission of information, protection and production will come to the fore in the next periods (Sener, 2012; cite in; Kentor, 2015). This emphasis is important considering the transformation context in $\mathrm{DE}$ during the Covid-19 (pandemic) process. For the first time, most of the compulsory education in the world and in Turkey takes place in digital environment with the DE system (Eken, Tosun, \& Tuzcu Eken, 2020). The practices related to education 
and training during the pandemic process in Turkey can be listed as follows: Political practices in education: From faceto-face education to the DE process in formal and non-formal education; Transition decisions from DE process to face-to-face education (practical decisions for DE taken by Ministry of National Education and council of Higher Education [CoHE]). Economic, cost and access factors in education: Tablet support campaigns of MoNE, other official institutions and NGOs for access to compulsory education, Education Information Network (EIN) TV installation, assistance, support and mobile EIN service units within the MoNE. Educational technology: Creating the required content about DE on the MoNE webpage and organizing in-service training, online seminars, introducing, procuring and using DE interface programs, and the transition of some universities to DE by completing their DE infrastructures. Education continues in pre-school, primary, secondary and higher education with the DE during the pandemic process.

During the pandemic process, education and training all over the world transformed into the DE system. This urgent transformation also leads to the emergence of some problems. Durak, Çankaya and İzmirli (2020), define prominent problematic issues in the DE process in higher education as the education process of the instructors, the technical details in making the system widely available and the integration of different systems. The existence of these problems in compulsory education contradicts with the principle of equal opportunity in education. In other studies, the prominent problems in education and training during the DE process are defined as communication problems, causing inequality of access to service and opportunity, and assessment-evaluation problems (Özdoğan \& Berkant, 2020; Eken, Tosun, \& Tuzcu Eken, 2020). It is also stated that the DE should be applied together with the face-to-face training method rather than the compulsory education process using the DE method alone (Duman, 2020). There are also studies indicating that there are problems in teaching physical education and special education and preschool education with the DE system (İnan, 2020; Kurt \& Kurtoğlu Erden, 2020; Yıldız \& Bektaş, 2020).

\section{"Research trends" studies}

Research trend studies are seen as a synthesis of researches on a discipline (Ozan \& Köse, 2014). It may contain information about the period, type and content of the researches. Ozan and Köse (2014) state that research trends and research will change over the years in terms of content and method and the discipline in which the results of the research trends study are presented, is presented with its past and present and so that predictions for the future can be made.

It is known that studies of research trends belonging to many disciplines and especially educational sciences have been carried out. Some studies on research trends are presented in Table 1.

Table 1 presents information about the researches, including sample size, years and resources in the field of educational sciences and especially in the field of DE. There are research trends studies a few of fields including DE. In terms of sampling coverage year used in research in the field of DE, 2017 is the most recent. A recent literature review of the research trends in DE research, especially covering the pandemic process, has not been found.

\section{Problem statement}

During the pandemic process, many countries started to carry out almost all of their education and training activities with the DE method. The effect of the pandemic process on research trends in the field of DE is an issue that should be taken into consideration. Studies in the field of DE can be investigated in terms of form, methodology and content. We believe that there is a need for a classification regarding the subject (content) studied in the field of DE field studies. Among the studies conducted in the field of DE, Zawacki-Richter (2009) offers a Classification of Research Areas in DE (RADE), which was carried out with Delphi technique for content classification. RADE covers a total of 15 research areas at upper (macro), middle (meso) and lower (micro) levels for DE research areas. Levels, areas, area numbers and descriptions of these areas determined by Zawacki-Richter (2009) are presented in Table 2 .

As presented in Table 2, 15 areas in total are listed as DE research areas at three levels by Zawacki-Richter (2009). In the pandemic process, the transition to education and training with the DE method comes along some problems. Research trends in DE (in terms of formal, methodology and content) and the effect of pandemic process on DE, which will contribute to the literature of $\mathrm{DE}$, especially covering the pandemic period, constitute the problem situation for this research.

\section{Objective}

The purpose of the present research is to consider the development periods of DE in a historical perspective and to reveal the formal features, contents and approaches of the studies on DE by taking into account the DE practices during the pandemic process. The main purpose of the present research is to examine research trends and changes in trends in research related to distance education. In accordance with this general purpose, answers to the following questions are sought:

- What forms does distance education research including the pandemic process take?

- What methods does distance education research including the pandemic process use? 
Table 1: Some Examples of Studies Conducted on Research Trends

\begin{tabular}{|c|c|c|c|c|}
\hline Author(s) & Sample size & Sample type / year & Source of the sample & Research field \\
\hline Ozan and Köse (2014) & 380 & $\begin{array}{l}\text { Dissertation / 2007- } \\
2011\end{array}$ & ULAKBİM & $\begin{array}{l}\text { Education programs } \\
\text { and training }\end{array}$ \\
\hline Kurt and Erdoğan (2015) & 38 & $\begin{array}{l}\text { Thesis/ dissertation } \\
\text { and Research article / } \\
2004-2013\end{array}$ & $\begin{array}{l}\text { EBSCOhost, ULAKBIM, ASOS index, CoHE, } \\
\text { Scholar Google }\end{array}$ & $\begin{array}{l}\text { Program evaluation } \\
\text { in education }\end{array}$ \\
\hline Tabak (2009) & 38 & $\begin{array}{l}\text { Thesis/ dissertation } \\
\text { and Research article / } \\
\text { 2006-2017 }\end{array}$ & $\begin{array}{l}\text { CoHE, } \\
\text { ULAKBIM }\end{array}$ & Math education \\
\hline Gür Erdoğan (2020) & 758 & $\begin{array}{l}\text { Research article / 2016- } \\
2020\end{array}$ & web of science & Lifelong learning \\
\hline Günay and Aydın (2015) & 39 & $\begin{array}{l}\text { Thesis/ dissertation, } \\
\text { Research article, } \\
\text { conference paper, book } \\
\text { / 2005-2014 }\end{array}$ & CoHE, ERIC & $\begin{array}{l}\text { Multicultural } \\
\text { education }\end{array}$ \\
\hline $\begin{array}{l}\text { Polat Hopcan, Yahşi and } \\
\text { Hopcan }(2020)\end{array}$ & 52 & $\begin{array}{l}\text { Thesis/ dissertation / } \\
\text { 1990-2020 }\end{array}$ & $\begin{array}{l}\text { ERIC, SCOPUS, OpenAIRE, SSCI, ScienceDirect, } \\
\text { TRDizin, Complementary Index }\end{array}$ & $\begin{array}{l}\text { Education } \\
\text { Management }\end{array}$ \\
\hline $\begin{array}{l}\text { Bozkurt, Kumtepe, Kumtepe, } \\
\text { Aydın, Bozkaya, and Aydın } \\
(2015)\end{array}$ & 61 & $\begin{array}{l}\text { Dissertation / 1986- } \\
2014\end{array}$ & $\mathrm{CoHE}$ & $\mathrm{DE}$ \\
\hline $\begin{array}{l}\text { Gökmen, Uysal, Yasar, } \\
\text { Kirksekiz, Güvendi, and } \\
\text { Horzum (2017) }\end{array}$ & 380 & $\begin{array}{l}\text { Thesis/ dissertation / } \\
\text { 2005-2014 }\end{array}$ & $\mathrm{CoHE}$ & $\mathrm{DE}$ \\
\hline $\begin{array}{l}\text { Zengin, Şengel and Özdemir } \\
\text { (2018) }\end{array}$ & 76 & $\begin{array}{l}\text { Thesis/ dissertation, } \\
\text { research article, } \\
\text { conference paper / } \\
2007-2017\end{array}$ & $\mathrm{CoHE}$ & $\mathrm{DE}$ \\
\hline $\begin{array}{l}\text { Bağriaçık Yılmaz and Banyard } \\
(2020)\end{array}$ & 154 & $\begin{array}{l}\text { Research article /2000- } \\
2016\end{array}$ & web of science & $\mathrm{DE}$ \\
\hline $\begin{array}{l}\text { Zawacki-Richter, Backer and } \\
\text { Vogt (2009) }\end{array}$ & 695 & $\begin{array}{l}\text { Research article / 2000- } \\
2008\end{array}$ & $\begin{array}{l}\text { Open Learning (OL), Distance Education (DE), } \\
\text { the American Journal of Distance Education } \\
\text { (AJDE), the Journal of Distance Education (JDE), } \\
\text { and the International Review of Research in Open } \\
\text { and Distance Learning (IRRODL) }\end{array}$ & $\mathrm{DE}$ \\
\hline $\begin{array}{l}\text { Zawacki-Richter, Alturki and } \\
\text { Aldraiweesh (2017) }\end{array}$ & 580 & $\begin{array}{l}\text { Research article / 2000- } \\
2015\end{array}$ & $\begin{array}{l}\text { International Review of Research in Open and } \\
\text { Distributed Learning }\end{array}$ & $\mathrm{DE}$ \\
\hline
\end{tabular}

- What research area does distance education research including the pandemic process involve?

\section{Significance}

The present research is significant as it will

- Identify and comparatively analyze DE research trends, including the pandemic process,

- Reveal the effect of the pandemic process on DE,

- Guide future research in the field of DE,

- the rate of use of which in education has increased due to scientific-technological and other developments.

\section{Method}

\section{Research Design}

The data of the present research are based on document review and were collected via in-depth examination of the research articles. The present research, prepared with document data, is identified as a document review in the qualitative research tradition. Qualitative research is a suitable method for obtaining in-depth information in the examination of situations and cases, and document analysis also covers the examination of documents containing information about the phenomenon or facts to be investigated (Yıldırım \& Şimşek, 2013). The present research studies the research trends of the articles published in the field of $\mathrm{DE}$ and the changes in the research tendencies during the pandemic process in terms of form, methodology and content.

\section{Population and Sample}

The sample of the present research consists of 333 articles $(\mathrm{N}=333)$. The articles published in the field of $\mathrm{DE}$ between 2017-2020 and included in the Dergipark database constitute the sample of this research. Dergipark hosts the publications of refereed journals in electronic environment and is an important database, which was established by Ulakbim in order to "provide measurable clean data for TR Index and 
National Citation Index", and it contains articles from 2015 journals in 2020 and has a daily average of 100000 users (Dergipark). In March 2021, the terms "distance education", "distance learning", "blended learning", "mobile learning", "open education" (both in English and Turkish) were searched in quotation marks and only in article title for the dates between 01.01.2017 and 31.12.2020 in the Dergipark database. Remaining articles process presented in Table 3.

Table 2: Levels, Areas, Area Numbers and Definitions of These Fields by Zawacki-Richter (2009)

Levels Areas in terms of levels: Definitions

1. Macro level: Distance education systems and theories

1. Access, equity and ethics: Democratization and limited resources in access to DE, finding qualified education ways for those with weak infrastructure; issues referring to the sustainability of DE in developing areas

2. Globalization of education and cross-cultural aspects: Issues referring to market development, global environments and learning - teaching, professional development in DE

3. Distance teaching systems and institutions: Institutional partnerships and the impact of institutions in the development of DE delivery systems and international programs

4. Theories and models: Issues related to the theoretical framework and foundations

5. Research methods in distance education and knowledge transfer: Methodological thought, research, writing and literature reviews in DE

2. Meso level: Management, organization and technology

6. Management and organization: Strategy, policy, management and organizational infrastructure issues in $\mathrm{DE}$

7. Costs and benefits: Issues referring to cost, business models, productivity in DE

8. Educational technology: Innovation and trends in educational technologies for DE

9. Innovation and change: Issues referring to educational innovation to support change in institutions

10. Professional development and faculty support: Professional development and faculty member support for innovation and change

11. Learner support services: Issues referring to services and organizations supporting learners

12. Quality assurance: Issues referring to accreditation and quality standards in UE

3. Micro level: Teaching and learning in distance education

13. Instructional design; practices in education: Issues referring to the design process for the Curriculum and for instructional purposes

14. Interaction and communication in learning communities: Research issues on instructional design that encourage interaction, reflection and collaboration within the online learning process

15. Learner characteristics: Issues related to socio-economic background, learning styles, tendencies, behavior patterns, learning styles, competencies of learners

Table 3: The process of Reaching Articles in Dergipark in March-2021

\begin{tabular}{|c|c|}
\hline Operation & Number of articles \\
\hline $\begin{array}{l}\text { Total Articles which the terms "distance education", "distance learning", "blended learning", "mobile learning", "open education" } \\
\text { (both in English and Turkish) were searched in quotation marks and only in article title for the dates between 01.01.2017 and } \\
\text { 31.12.2020 in the Dergipark database. }\end{array}$ & 453 \\
\hline Duplicate publications & 99 \\
\hline Letters to the editors & 5 \\
\hline Conference papers/abstracts & 7 \\
\hline \multicolumn{2}{|l|}{ Unreachable link } \\
\hline Remaining articles & \\
\hline
\end{tabular}


As presented in Table 3, with the searches, a total of 453 publications were found in the field of $\mathrm{DE}$ between the aforementioned dates. With further examination, duplicate publications (99), letters to the editors (5), conference papers / abstracts (7) and unreachable links (9) were removed from these publications, and the remaining 333 articles were included in the sample of the present research. Considering that previous field trend studies had sample sizes varying between 38 and 695 and the sample consists of thesis and (or) article studies, the number and type of the sample in the present is adequate enough in number and characteristics to reveal the research tendencies in $\mathrm{DE}$.

\section{Data Collection Tools}

1. Distance Education Article Review Form (DEARF) and 2. Research Areas in DE (RADE) are the data collection tools of the present research.

- Distance Education Article Review Form (DEARF): DEARF was developed by the researcher during this research process, using another form previously developed by Ozan and Köse (2014). DEARF was reviewed by an Assist. Prof. Dr. of DE and an Assoc. Prof. Dr. of Education Programs and Teaching, and after making the necessary arrangements in line with the recommendations, the form was finalized. DEARF was used in the present research to examine the articles in terms of form, method and content. DEARF is provided as Appendix 1

- Research Areas in DE (RADE): This form, which includes the $\mathrm{DE}$ research levels and areas, was created by Zawacki Richter (2009). These areas are presented in Table 2. There are studies on DE research trends utilizing this classification (levels and areas) in the related literature (Bağrıaçık \& Banyard, 2020; Bozkurt, et al., 2015; ZawackiRichter, et al., 2009; Zawacki-Richter, et al., 2017). RADE was used to classify the contents of the articles in the present research.

\section{Validity and Reliability}

Depth focused data was collected in order to provide validity and reliability for the present research, and in the sections required, explanations and detailed descriptions were made in terms of testability. In addition, sorting made in accordance with RADE by Zawacki-Richter (2009), which was used for the field classification of the article content for the third research question, was consulted for the verification. An Assoc. Prof. Dr. of educational sciences at the University of Gaziantep also sorted the articles in the RADE according to their content and as a result, it was found that there was $85 \%$ similarity between the two sorting. After exchanging views for $15 \%$ difference, an consensus was reached in the sorting.

\section{Data Collection}

Data collection process following the research purpose formed in accordance with the problem statement and research questions formed in accordance with this purpose is presented in Figure 4.

For this research, first the articles were obtained from the Dergipark database; filed according to years and author surnames, and other publications such as abstracts, letters to the editor other than the full text article were sorted out. Then the articles were analyzed using the DEARF data collection tool. After the form and method features of the articles were transferred to the form, the research areas of the articles were transferred to DEARF within the framework of RADE defined by Zawacki - Richter (2009). An example of defining the research areas and research levels of the article content in accordance with the RADE ranking is presented in Table 4.

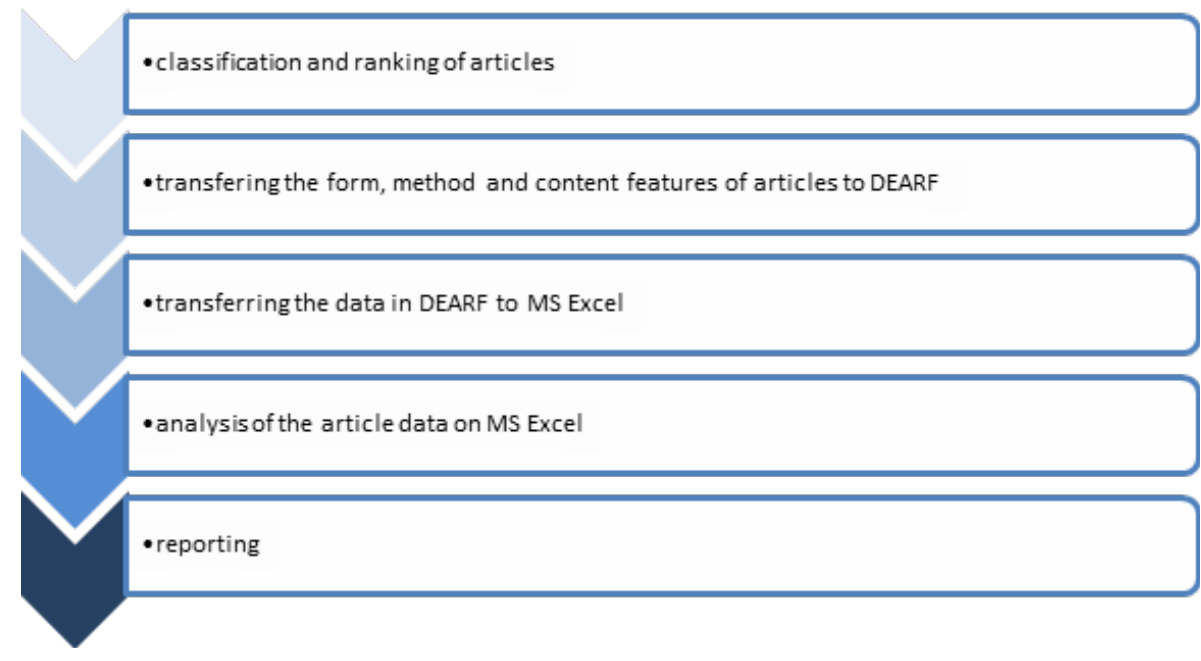

Figure 4. Data Collection Process 
Table 4: An Example of Defining the Research Area and Level of Articles

\begin{tabular}{|c|c|c|c|c|}
\hline Author(s)/ year & Title & Subject & $\begin{array}{l}\text { Research area } \\
\text { number }\end{array}$ & $\begin{array}{l}\text { Research level } \\
\text { number }\end{array}$ \\
\hline $\begin{array}{l}\text { Utami, Winarni, } \\
\text { Handayani and } \\
\text { Zuhairi/2020 }\end{array}$ & $\begin{array}{l}\text { When and Who Dropouts from Distance } \\
\text { Education }\end{array}$ & $\begin{array}{l}\text { A study on the students' not being able to } \\
\text { attend the DE }\end{array}$ & 1 & 1 \\
\hline Öztürk/2017 & $\begin{array}{l}\text { Academic Needs of International Learners and } \\
\text { Distance Education }\end{array}$ & Problems international students face in DE & 2 & 1 \\
\hline Can/ 2020 & $\begin{array}{l}\text { Coronavirus (Covid-19) pandemic and its } \\
\text { pedagogical reflections: Open and distance } \\
\text { education practices in Turkey }\end{array}$ & $\begin{array}{l}\text { The impact of the pandemic process on } \\
\text { DE systems }\end{array}$ & 3 & 1 \\
\hline $\begin{array}{l}\text { Keskin and } \\
\text { Akyıldı/2017 }\end{array}$ & $\begin{array}{l}\text { Discussion on the applicability of the briefing } \\
\text { method on open and distance learning: } \\
\text { animated and scenarian expression applications }\end{array}$ & $\begin{array}{l}\text { A study on concise presentation techniques } \\
\text { in } \mathrm{DE}\end{array}$ & 4 & 1 \\
\hline Thomas/2018 & $\begin{array}{l}\text { Technology in mathematics and science } \\
\text { distance education: Automated textual analysis } \\
\text { of articles and proceedings papers using } \\
\text { leximancer }\end{array}$ & A literature review of $\mathrm{DE}$ & 5 & 1 \\
\hline $\begin{array}{l}\text { Durnalı and } \\
\text { Koşar/2019 }\end{array}$ & $\begin{array}{l}\text { Analysis of the organizational goals of a } \\
\text { distance education center: An example of a } \\
\text { public university }\end{array}$ & $\begin{array}{l}\text { A study on the examination of a DE center } \\
\text { in the context of organizational goals }\end{array}$ & 6 & 2 \\
\hline $\begin{array}{l}\text { Kilınç, Yazıc1, } \\
\text { Günsoy and } \\
\text { Günsoy/2020 }\end{array}$ & $\begin{array}{l}\text { Perceptions and opinions of graduates about } \\
\text { the effects of open and distance learning in } \\
\text { Turkey }\end{array}$ & $\begin{array}{l}\text { A study investigating the contribution of } \\
\text { the Open Education System to the increase } \\
\text { of economic and social welfare in Turkish } \\
\text { higher education. }\end{array}$ & 7 & 2 \\
\hline Aktürk/2020 & $\begin{array}{l}\text { Restructuring the distance education business } \\
\text { process with the perspective of education } 4.0 \text { : } \\
\text { Kilis } 7 \text { Aralık University sample }\end{array}$ & $\begin{array}{l}\text { A study on structuring the DE process in } \\
\text { the context of education } 4.0\end{array}$ & 8 & 2 \\
\hline $\begin{array}{l}\text { Devran and } \\
\text { Elitaș/2017 }\end{array}$ & Distance education: Opportunities and threats & $\begin{array}{l}\text { A study examining the opportunities and } \\
\text { problems of DE in Turkey. }\end{array}$ & 9 & 2 \\
\hline Karyağd $1 / 2020$ & $\begin{array}{l}\text { Examination of the problems faced by } \\
\text { academicians teaching accounting and finance } \\
\text { group courses in distance education during the } \\
\text { Covid-19 epidemic: BEU example }\end{array}$ & $\begin{array}{l}\text { A study examining the problems of } \\
\text { academicians working in the field of DE }\end{array}$ & 10 & 2 \\
\hline $\begin{array}{l}\text { Mphahlele and } \\
\text { Makokotlela/ } 2020\end{array}$ & $\begin{array}{l}\text { Discourse on student participation in the } \\
\text { open distance learning using open educational } \\
\text { resources }\end{array}$ & $\begin{array}{l}\text { A study examining psychological counseling } \\
\text { and guidance services for students in DE }\end{array}$ & 11 & 2 \\
\hline $\begin{array}{l}\text { Ramdass and } \\
\text { Nemavhola/ } 2018\end{array}$ & $\begin{array}{l}\text { Quality practices: } \\
\text { An open distance learning perspective }\end{array}$ & Qualification research in DE & 12 & 2 \\
\hline Parwin/2017 & $\begin{array}{l}\text { A conceptual framework of virtual interactive } \\
\text { teacher training through open and distance } \\
\text { learning for the remote areas English teachers } \\
\text { of Bangladesh }\end{array}$ & $\begin{array}{l}\text { Virtual interactive teacher training program } \\
\text { development }\end{array}$ & 13 & 3 \\
\hline $\begin{array}{l}\text { Gümüş, Kavanoz } \\
\text { and Yılmaz/2017 }\end{array}$ & $\begin{array}{l}\text { The effect of delivering concept cartoons in } \\
\text { a mobile learning environment on learning } \\
\text { English idioms in secondary education }\end{array}$ & $\begin{array}{l}\text { An experimental study on the effect of } \\
\text { mobile learning on achievement }\end{array}$ & 14 & 3 \\
\hline $\begin{array}{l}\text { Özkök and } \\
\text { Bulutlu/2020 }\end{array}$ & $\begin{array}{l}\text { Examining the intention of university students } \\
\text { to use virtual classroom environments } \\
\text { simultaneously in distance education programs }\end{array}$ & $\begin{array}{l}\text { A structural equation modeling study on } \\
\text { student intentions in DE }\end{array}$ & 15 & 3 \\
\hline
\end{tabular}

As in the examples presented in Table 4, the content of the articles were placed in the related level and field created by Zawacki - Richter (2009). After the data were transferred to the DEARF, the examinations in the DEARF were transferred to the MS Excel program. Then, the data classified with MS Excel program were reported in accordance with the research questions. For the present research, approval was received from Gaziantep University-Social and Human Sciences Ethics Committee, which was dated 12.03.2021 and numbered 19. 


\section{Data Analysis}

In the present research, data analysis was done by descriptive analysis. Descriptive analysis refers to the interpretation of data in accordance with previously determined themes (Yıldirım \& Şimşek, 2013). Data tools and data analysis methods used for research questions related to the objectives of the present research are presented in Table 5.

As presented in Table 5, all data analysis for the present research were conducted by descriptive analysis. In line with descriptive analysis, reporting was made in accordance with the deductive approach. The DEARF DCT is used to reveal for general structure and methodology trends of articles and the RADE is used to reveal for research area.

\section{FINDINGS}

The present research studies the articles published in the field of DE between 2017 and 2020 in Dergipark in terms of research trends (form, methodology and content). Findings are presented in accordance with the order of research questions. The findings are prepared in accordance with the deductive approach. First of all, the most general findings are given in accordance with each research question, and then details are made for each research question.

\section{Findings for the first research question}

This section examines the forms of the articles. The number of articles examined within the scope of the research is 333. Figure 5 presents the ratio of research-review articles.

Table 5: Research Objectives, Data Collection Tools / Method / Analysis

\begin{tabular}{llll}
\hline $\begin{array}{l}\text { Research question } \\
\text { number }\end{array}$ & $\begin{array}{l}\text { Data collection } \\
\text { tool }\end{array}$ & $\begin{array}{l}\text { Data collection } \\
\text { method }\end{array}$ & Data analysis \\
\hline 1 & DEARF & $\begin{array}{l}\text { Document } \\
\text { analysis }\end{array}$ & $\begin{array}{l}\text { Descriptive } \\
\text { analysis }\end{array}$ \\
2 & DEARF & $\begin{array}{l}\text { Document } \\
\text { analysis }\end{array}$ & $\begin{array}{l}\text { Descriptive } \\
\text { analysis }\end{array}$ \\
3 & RADE $^{*}$ & $\begin{array}{l}\text { Document } \\
\text { analysis }\end{array}$ & $\begin{array}{l}\text { Descriptive } \\
\text { analysis }\end{array}$ \\
\hline
\end{tabular}

${ }^{\star}$ DE research levels and areas defined by Zawacki-Richter (2009)

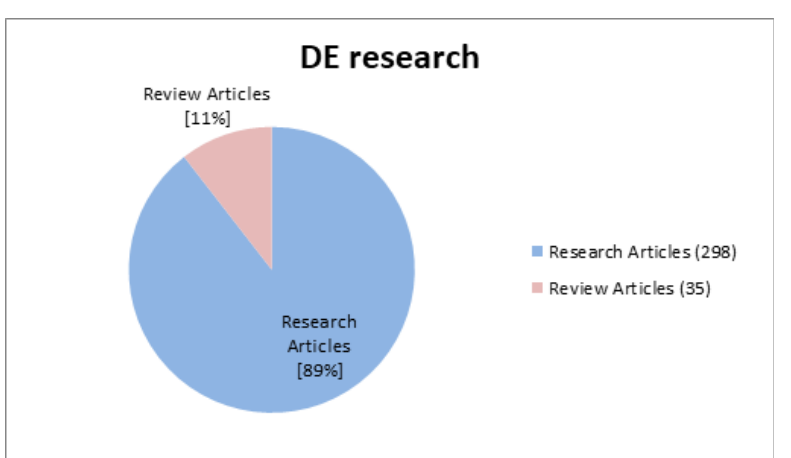

Figure 5: DE Review and Research Articles published between 2017-2020 ( $\mathrm{N}=333)$
As presented in Figure 5, most of the articles are research articles. The distribution of research-review articles by years is presented in Figure 6.

As presented in Figure 6, most of the articles are research articles, and the number of research articles nearly triples in 2020, which covers the pandemic process. Numbers and rates related to other formal features (language and keyword, number of author bibliography) of the articles in the field of DE are presented in Table 6.

As presented in Table 6, the highest number of articles were in Turkish language (208 - 62.5\%); with three keywords (107 - 32.20\%); by two authors (132 - 39.60\%) and used 21-30 references (83 - 24.90\%). In terms of the journal in which DE articles were published; it was 39 journals in 2017; 32 in 2018; 43 journals in 2019 and 81 in 2020. In addition, in 2020, the publication rate of articles in the field of DE has increased in journals belonging to other disciplines other than educational sciences. All of the articles published in the field of DE between 2017-2020 were published in 155 journals in total. The numbers of journals according to the number of articles published are presented in Table 7.

As presented in Table 7, the journal with the highest number of publications every year in the field of DE is the Turkish Online Journal of Distance Education (TOJDE). Although the National Education Journal did not been published in the field of DE in other years, all of its articles are in the special issue of Education in Turkey and in the World during the Epidemic Process, published in December 2020.

\section{Findings for the second research question}

This section studies the methodology of the articles. The methods used in the articles by years are presented in Table 8.

As presented in Table 8, while the quantitative research tendency was the most common in 2017, 2018 and 2019; in 2020 , the qualitative research became the most common method. The number of qualitative, quantitative, mixed method and review articles by years is presented in Figure 7.

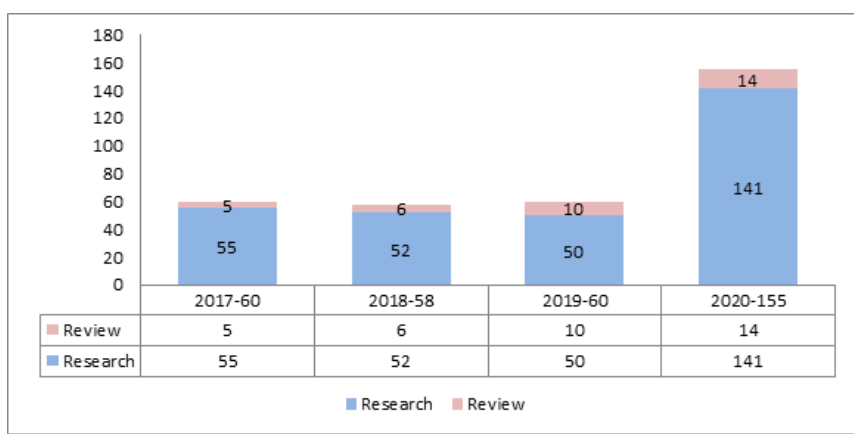

Figure 6: DE Review and Research Articles published between 2017-2020 ( $\mathrm{N}=333)$ 
Table 6: Formal Features of DE Articles published between 2017-2020 ( $\mathrm{N}=333)$

\begin{tabular}{|c|c|c|c|c|c|c|c|c|}
\hline Feature & & 2017 & 2018 & 2019 & 2020 & & Total & $\%$ \\
\hline \multirow[t]{4}{*}{ Language } & Turkish & 36 & 25 & 38 & 109 & & 208 & 62.50 \\
\hline & English & 24 & 33 & 22 & 45 & & 124 & 37.20 \\
\hline & Arabic & - & - & - & 1 & & 1 & .30 \\
\hline & Total & 60 & 58 & 60 & 155 & & 333 & 100. \\
\hline \multirow[t]{7}{*}{ Number of key words } & 2 & 1 & 1 & - & - & 2 & & .60 \\
\hline & 3 & 22 & 16 & 17 & 52 & 107 & & 32.20 \\
\hline & 4 & 19 & 14 & 24 & 40 & 97 & & 29.10 \\
\hline & 5 & 14 & 21 & 12 & 52 & 99 & & 29.70 \\
\hline & 6 & 3 & 6 & 5 & 8 & 22 & & 6.60 \\
\hline & $6+$ & 1 & - & 2 & 3 & 6 & & 1.80 \\
\hline & Total & 60 & 58 & 60 & 155 & 333 & & 100. \\
\hline \multirow[t]{7}{*}{ Number of authors } & 1 & 23 & 16 & 16 & 56 & 111 & & 33.40 \\
\hline & 2 & 23 & 20 & 24 & 65 & 132 & & 39.60 \\
\hline & 3 & 7 & 19 & 12 & 18 & 56 & & 16.80 \\
\hline & 4 & 5 & 2 & 5 & 10 & 22 & & 6.60 \\
\hline & 5 & 1 & 1 & - & 4 & 6 & & 1.80 \\
\hline & $5+$ & 1 & - & 3 & 2 & 6 & & 1.80 \\
\hline & Total & 60 & 58 & 60 & 155 & 333 & & 100. \\
\hline \multirow[t]{12}{*}{ Number of references } & $5-10$ & 2 & 4 & - & 3 & 9 & & 2.70 \\
\hline & $11-20$ & 13 & 5 & 13 & 24 & 55 & & 16.50 \\
\hline & $21-30$ & 17 & 13 & 12 & 41 & 83 & & 24.90 \\
\hline & $31-40$ & 11 & 14 & 11 & 35 & 71 & & 21.40 \\
\hline & $41-50$ & 8 & 10 & 8 & 20 & 46 & & 13.80 \\
\hline & $51-60$ & 3 & 7 & 5 & 12 & 27 & & 8.10 \\
\hline & $61-70$ & 3 & 2 & 5 & 8 & 18 & & 5.40 \\
\hline & $71-80$ & 2 & - & - & 5 & 7 & & 2.10 \\
\hline & $81-90$ & 1 & - & 2 & 3 & 6 & & 1.80 \\
\hline & $91-100$ & - & 1 & 1 & 1 & 3 & & .90 \\
\hline & $100+$ & - & 2 & 3 & 3 & 8 & & 2.40 \\
\hline & Total & 60 & 58 & 60 & 155 & 333 & & 100. \\
\hline
\end{tabular}

Table 7: Journal Information and Number of Articles Published in DE between 2017-2020 (N=333)

\begin{tabular}{|c|c|c|c|c|c|c|}
\hline Journal Name (abbreviation) & 2017 & 2018 & 2019 & 2020 & Total & $\%$ \\
\hline Turkish Online Journal of Distance Education (TOJDE) & 12 & 19 & 12 & 16 & 59 & 17.70 \\
\hline Milli Eğitim Dergisi (Journal of National Education) & - & - & - & 24 & 24 & 7.20 \\
\hline $\begin{array}{l}\text { Açıöögretim Uygulamaları ve Araştırma Dergisi (AUAD) (Journal of Open } \\
\text { Education Practices and Research) }\end{array}$ & 3 & 4 & 3 & 11 & 21 & 6.30 \\
\hline Educational Technology Theory and Practice (ETKU) & 2 & 1 & 1 & 1 & 5 & 1.50 \\
\hline Kastamonu Education Journal (KEJ) & 2 & - & - & 3 & 5 & 1.50 \\
\hline Online Academic Journal of Information Technology (ACIT-e) & 1 & 3 & 1 & - & 5 & 1.50 \\
\hline The Eurasia Proceedings of Educational and Social Sciences (EPESS) & 2 & 1 & - & 2 & 5 & 1.50 \\
\hline $\begin{array}{l}\text { Of the other } 148 \text { journals; two published four; three published 13; two articles were } \\
\text { published in } 28 \text { and one article in } 106 \text { journals. }\end{array}$ & 38 & 30 & 43 & 98 & 209 & 62.80 \\
\hline Total & 60 & 58 & 60 & 155 & 333 & 100. \\
\hline
\end{tabular}


As presented in Figure 7, the number of methods used in the articles varies over the years. The increase in the number of articles in qualitative method published in 2020 is also noteworthy. The information about the method and design of the articles is presented in Table 9.

As presented in Table 9, the most common design in the articles in total is descriptive screening in quantitative method (69 - 20.70\%); case study in qualitative method (95 28.60\%); Explanatory (16 - 4.80\%) design in mixed method. Other designs used in the articles are cluster analysis, a priori, quality design house, data mining and Delphi technique. The distribution of 325 data collection tools used in 310 articles reporting the use of any data collection tool is presented in Table 10.

Table 8: The Methods Used in the Articles by Years (N=333)

\begin{tabular}{|c|c|c|c|c|c|c|}
\hline Method & 2017 & 2018 & 2019 & 2020 & Total & $\%$ \\
\hline Quantitative & 26 & 27 & 26 & 53 & 132 & 39.60 \\
\hline Qualitative & 26 & 20 & 20 & 75 & 141 & 42.40 \\
\hline Mixed & 3 & 5 & 4 & 13 & 25 & 7.50 \\
\hline Review & 5 & 6 & 10 & 14 & 35 & 10.50 \\
\hline Total & 60 & 58 & 60 & 155 & 333 & 100. \\
\hline
\end{tabular}

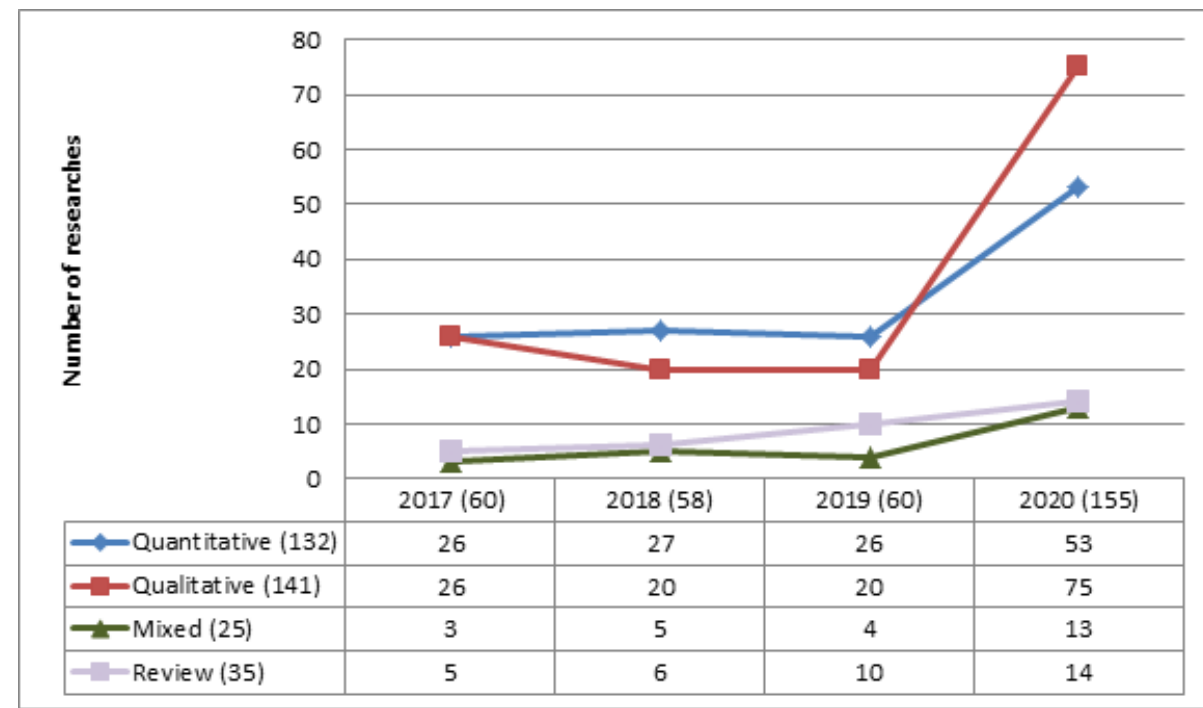

Figure 7: Distribution of the Methods Used in the Articles by Years

Table 9: The Number of the Methods and Design Used in the Articles by Years (N=333)

\begin{tabular}{|c|c|c|c|c|c|c|c|}
\hline \multirow{2}{*}{$\frac{\text { Method }}{\text { Quantitati }}$} & \multirow[t]{2}{*}{ Design } & \multirow[t]{2}{*}{2017} & \multirow[t]{2}{*}{2018} & 2019 & 2020 & \multirow[t]{2}{*}{ Total } & $\%$ \\
\hline & & & & & & & \\
\hline & True experimental & - & 2 & 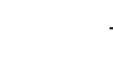 & - & 2 & .60 \\
\hline & Quasi experimental & 6 & 4 & 4 & 3 & 17 & 5.10 \\
\hline & Weak experimental & - & 1 & 2 & - & 3 & .90 \\
\hline & Descriptive screening & 8 & 13 & 14 & 34 & 69 & 20.70 \\
\hline & Relational screening & 8 & 4 & 3 & 10 & 25 & 7.50 \\
\hline & Meta-analysis & - & 1 & . & - & 1 & .30 \\
\hline & Scale development / adaptation & - & - & 2 & 2 & 4 & 1.20 \\
\hline & Structural Equation Modeling & 1 & 2 & 1 & 2 & 6 & 1.80 \\
\hline & Other & 3 & - & . & 2 & 5 & 1.50 \\
\hline & Total & 26 & 27 & 26 & 53 & 132 & 39.60 \\
\hline
\end{tabular}




\begin{tabular}{|c|c|c|c|c|c|c|c|}
\hline Method & Design & 2017 & 2018 & 2019 & 2020 & Total & $\%$ \\
\hline \multicolumn{8}{|c|}{ Qualitative } \\
\hline & Phenomenology & 6 & 2 & 2 & 13 & 23 & 6.90 \\
\hline & Case study & 17 & 12 & 13 & 53 & 95 & 28.60 \\
\hline & Action research & 1 & - & - & - & 1 & .30 \\
\hline & Literature review & 2 & 6 & 4 & 9 & 21 & 6.30 \\
\hline & Other & - & - & 1 & - & 1 & .30 \\
\hline & Total & 26 & 20 & 20 & 75 & 141 & 42.30 \\
\hline \multicolumn{8}{|l|}{ Mixed } \\
\hline & Explanatory & 2 & 4 & 4 & 6 & 16 & 4.80 \\
\hline & Exploratory & - & 1 & - & 4 & 5 & 1.50 \\
\hline & Variation & 1 & - & - & 3 & 4 & 1.20 \\
\hline & Total & 3 & 5 & 4 & 13 & 25 & 7.50 \\
\hline Review & Review & 5 & 6 & 10 & 14 & 35 & 10.50 \\
\hline Total & & & & & & 333 & 100. \\
\hline
\end{tabular}

Table 10:Data Collection Tools Used in Articles by Years ( $\mathrm{n}=325)$

\begin{tabular}{|c|c|c|c|c|c|c|}
\hline Data collection tool & 2017 & 2018 & 2019 & 2020 & Total & $\%$ \\
\hline Interview & 13 & 4 & 8 & 47 & 72 & 22 \\
\hline Document analysis & 14 & 21 & 13 & 26 & 74 & 23 \\
\hline Test, questionnaire and scale & 21 & 27 & 29 & 74 & 151 & 46 \\
\hline Assessment (Achievement, attitude and alternative) & 10 & 5 & 4 & 2 & 21 & 7 \\
\hline Other (Web, personal information form, etc.) & 3 & - & 2 & 2 & 7 & 2 \\
\hline Total & 61 & 57 & 56 & 151 & 325 & 100 \\
\hline
\end{tabular}

As presented in Table 10, the most commonly used data collection tools in the articles are test, questionnaire and scale sort of tools (151-46\%). Most of the data collected through interviews and tests, surveys and scales among the data collection tools used in the articles were obtained online in 2020. The distribution of sample size by years in 239 articles reporting to have used samples (participants) is presented in Table 11.

As presented in Table 11, how many sample (participants) size used in the articles by years, the most commonly employed sample (participant) size in the articles is $31-100$ participants (68-28.50\%). In the articles studied in the field of DE for the present research, 132 used quantitative method, 141 qualitative method and 25 mixed methods, a total of 349 types of analyzes were performed in a total of 298 studies. Review studies were not included in Table 12 since they included no analyses $(n=35)$. The distribution of data analysis methods used in the articles by years is presented in Table 12 .

As presented in Table 12, the most commonly employed data analysis method in the articles is predictive analysis in quantitative method (115 - 33\%); content analysis in qualitative method (120 - 34.40\%), and content analysis in mixed method (17 - 4.90\%). Other analysis methods employed in the articles are cluster analysis, sentiment analysis, leximancer and swot analysis.

\section{Findings for the third research question}

This section studies the articles in terms of content. The content of the articles was classified in accordance with the Research Areas in DE (RADE), which was reported by Zawacki (2009) and presented in Table 2. As presented in Table 2, research areas in $\mathrm{DE}$ are defined as upper, middle and lower level. The distribution of research areas in the articles is presented in Figure 8.

As presented in Figure 8, the common most research area among the sample is the lower level (183 - 55\%) research area. The ranking of the article contents according to the fields is presented in Table 13 in decreasing order.

As presented in Table 13, most of the articles are included in three categories in terms of content; instructional 
Table 11: Distribution of Sample (participants) Size Used in the Articles by Years ( $\mathrm{n}=239)$

\begin{tabular}{lrrrrrrr}
\hline Sample (participants) size & 2017 & 2018 & 2019 & 2020 & Total & $\%$ & 10 \\
\hline $0-10$ & 4 & 3 & 3 & 14 & 24 & 14.60 \\
$11-30$ & 7 & 3 & 5 & 20 & 35 & 28.50 \\
$31-100$ & 17 & 12 & 11 & 28 & 68 & 25.10 \\
$101-300$ & 9 & 10 & 10 & 31 & 60 & 15.90 \\
$301-1000$ & 5 & 8 & 10 & 15 & 38 & 5.90 \\
$1000+$ & 2 & 2 & 2 & 8 & 14 & 100. \\
\hline Total & 44 & 38 & 41 & 116 & 239 & \\
\hline
\end{tabular}

Table 12: Distribution of Data Analysis Methods Used in Articles by Years ( $\mathrm{n}=349)$

\begin{tabular}{llllllll}
\hline Data analysis method & & 2017 & 2018 & 2019 & 2020 & Total & $\%$ \\
\hline Quantitative & & & & & & & \\
& Descriptive analysis & 5 & 14 & 5 & 10 & 34 & 9.70 \\
& Predictive analysis & 22 & 23 & 25 & 45 & 115 & 33 \\
& Other & - & - & - & 1 & 1 & .20 \\
& Total & 27 & 37 & 30 & 56 & 150 & 42.90 \\
Qualitative & & & & & & \\
& Content analysis & 20 & 17 & 16 & 67 & 120 & 34.40 \\
& Descriptive analysis & 4 & 2 & 5 & 8 & 19 & 5.40 \\
& Other & - & 1 & - & 2 & 3 & .80 \\
\multirow{5}{*}{ Mixed } & Total & 24 & 20 & 21 & 87 & 152 & 43.60 \\
& & & & & & & \\
& (Quantitative) descriptive analysis & 2 & 2 & - & 6 & 10 & 2.90 \\
& Predictive analysis & - & 3 & 4 & 7 & 14 & 4 \\
& Content analysis & 3 & 2 & 4 & 8 & 17 & 4.90 \\
& (Qualitative) descriptive analysis & - & 2 & - & 4 & 6 & 1.70 \\
& Total & 5 & 9 & 8 & 25 & 47 & 13.50 \\
\hline Total & & & & & & 349 & 100.
\end{tabular}

design: practices in education (74-22.20\%); interaction and communication in learning communities (58-17.40) and learner characteristics (51-15.40). The distribution of the articles as upper, middle and lower-level research areas in terms of content by years is presented in Table 14.

As presented in Table 14, the most common content area for the articles is the instructional design: practices in education (58), which is included in lower-level research area category, while the least common is innovation and change (1), which is included in the middle level category.

\section{Discussion}

During the pandemic process, education has mostly transformed into DE both in Turkey and the world. The present research studied whether this transformation in the field of

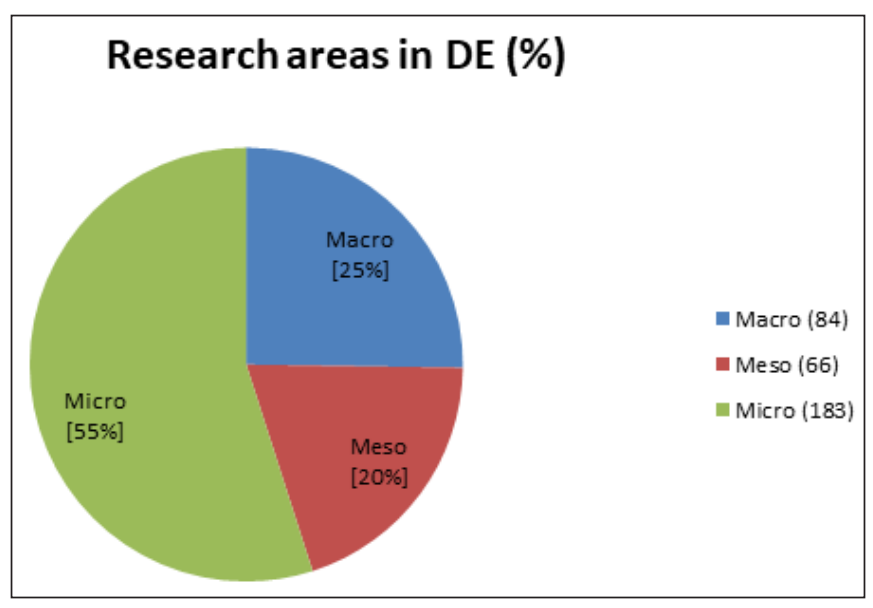

Figure 8: DE Research Areas in Articles ( $\mathrm{N}=333)$ 
Table 13: Ranking of Contents in Articles by Research Areas (N=333)

\begin{tabular}{|c|c|c|c|c|}
\hline Rank & Research area & Level & $F$ & $\%$ \\
\hline 1 & Instructional design; practices in education & 3 & 74 & 22.20 \\
\hline 2 & Interaction and communication in learning communities & 3 & 58 & 17.40 \\
\hline 3 & Learner characteristics & 3 & 51 & 15.40 \\
\hline 4 & Research methods in distance education and knowledge transfer & 1 & 24 & 7.20 \\
\hline 5 & Distance teaching systems and institutions & 1 & 23 & 6.90 \\
\hline 6 & Theories and models & 1 & 22 & 6.60 \\
\hline 7 & Management and organization & 2 & 16 & 4.80 \\
\hline 7 & Educational technology & 2 & 16 & 4.80 \\
\hline 8 & Professional development and faculty support & 2 & 13 & 3.90 \\
\hline 9 & Access, equity and ethics & 1 & 12 & 3.60 \\
\hline 9 & Quality assurance & 2 & 12 & 3.60 \\
\hline 10 & Costs and benefits & 2 & 6 & 1.80 \\
\hline 11 & Globalization of education and cross-cultural aspects & 1 & 3 & .90 \\
\hline 12 & Learner support services & 2 & 2 & .60 \\
\hline 13 & Innovation and change & 2 & 1 & .30 \\
\hline Total & & & 333 & 100. \\
\hline
\end{tabular}

Table 14: Distribution of Articles in terms of Content in the Field of DE by Upper, Intermediate and Lower-Level Research Areas (N=333)

\begin{tabular}{|c|c|c|c|c|c|c|}
\hline Level & (Area number) Research area & 2017 & 2018 & 2019 & 2020 & Total \\
\hline \multirow[t]{6}{*}{ Macro } & & & & & & 84 \\
\hline & (1) Access, equity and ethics & 2 & 2 & 1 & 7 & 12 \\
\hline & (2)Globalization of education and cross-cultural aspects & 1 & 1 & 1 & - & 3 \\
\hline & (3) Distance education systems and institutions & - & - & - & 23 & 23 \\
\hline & (4) Theories and models & 7 & 4 & 8 & 3 & 22 \\
\hline & (5) Research methods in distance education and knowledge transfer & 2 & 7 & 4 & 11 & 24 \\
\hline \multirow[t]{8}{*}{ Meso } & & & & & & 66 \\
\hline & (6) Management and organization & 5 & 3 & 4 & 4 & 16 \\
\hline & (7) Costs and benefits & - & 3 & - & 3 & 6 \\
\hline & (8) Educational technology & - & 4 & 4 & 8 & 16 \\
\hline & (9) Innovation and change & 1 & - & - & - & 1 \\
\hline & (10) Professional development and faculty support & 2 & 2 & 3 & 6 & 13 \\
\hline & (11) Learner support services & - & - & - & 2 & 2 \\
\hline & (12) Quality assurance & 4 & 2 & 2 & 4 & 12 \\
\hline \multirow[t]{4}{*}{ Micro } & & & & & & 183 \\
\hline & (13) Instructional design; practices in education & 12 & 10 & 7 & 45 & 74 \\
\hline & (14) Interaction and communication in learning communities & 8 & 17 & 19 & 14 & 58 \\
\hline & (15) Learner characteristics & 16 & 3 & 7 & 25 & 51 \\
\hline Total & & 60 & 58 & 60 & 154 & 333 \\
\hline
\end{tabular}

education and the pandemic process have had an effect on the research trends of DE.

\section{Discussion on the first research question}

In terms of form, the vast majority of the articles examined within the scope of the present research are research articles
(298 - 89\%) and some review articles (35-11\%). Some remarkable points are that research articles among the articles published in the field of DE during the pandemic period (in 2020) increased significantly (approximately three times) compared to other years, that the articles were mostly published in Turkish (208 - 62.5\%); the number of keywords 
is three (107 - 32.20\%); the number of authors is two (132 $39.60 \%)$ and the number of references is between 21 and 30 (83 - 24.90\%). In the study conducted Zawacki et al. (2009), it was reported that the number of articles published between 2000-2008 was close to each other every year, most articles had one author and the most common range for the number of references was between 16 and 20. In Bağriaçık and Yanyard (2020) reported that the number of articles published between 2000 and 2016 increasws every year and most of these articles had two authors. It was also found that the articles were mostly published in the Turkish Online Journal of Distance Education (TOJDE) (59 - 17.70\%) and the number of articles related to the field of DE increased in many journals within the scope of other disciplines in 2020 (pandemic period).

\section{Discussion on the second research question}

In terms of methodology, it was found that the use qualitative method has increased in 2020 (during the pandemic process) and the qualitative method was used in $141(42.40 \%)$ articles in total. Unlike this finding, Zawacki et al. (2009), Bozkurt et al. (2015) and Bağrıaçık and Yanyard (2020) stated that the most commonly used method in the articles was the quantitative method. However, it should be taken into account for the present research that the qualitative method is getting ahead with the increase in 2020 (during the pandemic process). In terms of design, most of the articles were designed in accordance with case study (95-28.60\%), which is a qualitative method and descriptive screening (69-20.70\%) designs, which is a quantitative method. Similarly, Bozkurt et al. (2015) reported case study as the most common qualitative method, and differently, Bozkurt et al. (2015), Bağrıaçı and Yanyard (2020) stated that experimental design was the most commonly used design in quantitative method. The fact that data could be collected online only in DE for all education and training and almost all scientific studies during the pandemic epidemic can be the reason why it was not as possible to conduct as many experimental design studies. According to the findings of the present research, the most commonly employed data collection tools in the articles are tests, questionnaires and scales (74-23\%) and interviews (72-22\%). Bağrıç̧ı and Yanyard (2020) and Bozkurt et al. (2015) reported in their studies that the most commonly employed data collection tools were questionnaires, diaries and interviews. It was also found that the most commonly employed sample size range in the articles (the number of participants) was between 31 and 100 (68-28.50\%). Similarly, Bağriaçık and Yanyard (2020) stated that the sample size between 31-100 was the most commonly employed sample size. In addition, it was found that data analysis in the articles was mostly conducted with predictive analysis in quantitative method (115-33\%) and content analysis in qualitative method (120-34.40\%). Similarly, Bozkurt et al.
(2015) reported that predictive analysis was the most common quantitative method, while content analysis was the most common qualitative method. It was found within the present research that, in 2020 (during the pandemic process), there was a decrease in experimental design and an increase in descriptive screening design, and data collection (interviews, tests, questionnaires, scales, etc.) was mostly conducted online.

\section{Discussion on the third research question}

For the present research, contents of the articles were examined within the framework of Research Areas in DE (RADE) defined by Zawacki (2009). It was found that in terms of content, most of the articles were included in lower level (183 - 55\%). Most articles were in instructional design: practices in education (74$22.20 \%$ ) and least number of articles in innovation and change (1-.30\%) content areas. Similarly, Bozkurt et al. (2015) and Bağriaçık and Yanyard (2020) stated that the most common article content is at the level of instructional design: practices in education; yet at least common the level was access, equity and ethics; globalization of education and intercultural aspects; and levels of research methods in distance education and knowledge transfer. Zawacki et al. (2017) reported that the most common area used in the content of the articles was DE systems and institutions, and the least common was access, equality and ethics between 2000-2005; most common instructional design: practices in education and least common learner support services between 2006-2010; and most common instructional design: practices in education and least common was innovation and change between 2011-2015.

It is inevitable that the pandemic process will affect the field of education, as many other fields. DE has become an indispensable form of education in the pandemic process. However, along with the pandemic process (in 2020), many problematic issues have emerged, such as legal regulations, equality in access, infrastructure, restructuring of pre-school programs in the field, status of students with special needs, status of courses requiring special skills, assessment and evaluation in DE (Eken, Tosun, \& Tuzcu, 2020; İnan, 2020; Kurt \& Kurtoğlu Erden, 2020; Özdoğan \& Berkant, 2020; Yildız \& Bektaş, 2020).

\section{Conclusion}

The results obtained from the present research, which was conducted to study the changes in research trends in DE and DE research trends with the effect of pandemic are presented in accordance with the order of research questions below:

\section{Conclusion on the first research question}

Most of the articles are research articles and published in Turkish, and the total number of articles increased approximately three times in 2020 , which covers the pandemic 
process. Most of the articles were written by two authors and the number of references was mostly between 16 and 20. It was concluded that during the pandemic process (in 2020), the number of articles related to the field of DE has also increased within journals of other disciplines.

\section{Conclusion on the second research question}

While the quantitative method was the most common in the articles published in the field of DE until 2020, in 2020 (during the pandemic process), it was the qualitative method. The most commonly employed sample size/number of participants ranged between 31 and 100 and unlike previous years, the data obtained from the sample / participants in 2020 were collected online. In terms of data analysis, most common quantitative analysis method was predictive; and most common qualitative analysis method was content analysis. Experimental studies could not be conducted in the studies published during the pandemic process (decreased), the data obtained from the data sources were generally collected online and the case study method was the most common method.

\section{Conclusion on the third research question}

Most of the articles published between 2017-2020 in the DE were included in lower (micro) level and instructional design: practices in education in accordance with the research levels and fields offered by by Zawacki - Richter (2009). While the number of articles in the areas of instructional design: practices in education, distance education systems and institutions, learner characteristics has increased during the pandemic process; there were no studies within the subject areas of globalization of education and intercultural aspects and innovation and change (Korkman \& Çolak, 2021).

\section{SUgGeSTION}

As a result of the present research on the effect of the pandemic process on DE and research trends, the following suggestions can be made to the researchers for the further studies and practices to be carried out in the future:

- Studies to reveal the globalization of education and intercultural aspects in the field of DE,

- Management and organization research in the field of DE,

- Studies on learner support services in the field of DE,

- Research on the use of technology in the field of DE,

- Research on assessment and evaluation in the field of DE,

- Research on cost, access, equity and ethics in the field of DE.

\section{Limitation}

The articles in the Dergipark database, published between 2017-2020, including the terms distance education, mobile education, e-learning, transformed learning, open education (Turkish and English) in the title constitute the limitation of this research.

\section{ACKnOWledgement}

I would like to express my gratitude to Prof. Dr. Erdal BAY, who has contributed greatly with his ideas on conceptual framework and methodology.

\section{References}

Aktürk, C. (2020). Uzaktan eğitim iş sürecinin eğitim 4.0 perspektifiyle yeniden yapılandırılması: Kilis 7 Aralık Üniversitesi örneği. Akademik Araştırmalar ve Çalışmalar Dergisi (AKAD), 12(23), 322-339. Retrieved from https:// dergipark.org.tr/en/download/article-file/1088339

Allen, I. E. ve Seaman, J. (2011). Going the distance: Online education in the United States, 2011. Sloan Consortium. PO Box 1238, Newburyport, MA 01950.

Bagriacik Yilmaz, A. ve Banyard, P. (2020). Engagement in distance education settings: A trend analysis. Turkish Online Journal of Distance Education, 21(1), 101-120. https://doi.org/10.17718/ tojde.690362 https://doi.org/

Bozkurt, A. (2017). Türkiye'de uzaktan eğitimin dünü, bugünü ve yarını. Açıköğretim Uygulamaları ve Araştırmaları Dergisi, 3 (2), 85-124. Retrieved from https://dergipark.org.tr/tr/pub/ auad/issue $/ 34117 / 378446$

Bozkurt, A., Kumtepe, E. G., Kumtepe, A. T., Aydın, I. E., Bozkaya, M. ve Aydın, C. H. (2015). Research trends in Turkish distance education: A content analysis of dissertations, 1986-2014. European Journal of Open, Distance and E-learning, 18(2), 1-21. https://doi.org/10.1515/eurodl-2015-0010

Can, E. (2020). Coronavirüs (Covid-19) pandemisi ve pedagojik yansımaları: Türkiye' de açık ve uzaktan eğitim uygulamaları. Açıköğretim Uygulamaları ve Araştırmaları Dergisi, 6(2), 11-53. Retrieved from https://dergipark.org.tr/tr/pub/auad/ issue/55662/761354

Carlson, S. ve Carnevale, D. (2001). Debating the demise of NYU online. Chronicle of Higher Education, 48(16). Retrieved from https://eric.ed.gov/?id=EJ639380

Debeş, G. (2021). Distance learning in higher education duringthe COVID-19 Pandemic: advantages and disadvantages. International Journal of Curriculum and Instruction 13(2), 1109-1118.

Dergipark. Dergipark hakkında. Retrieved from https://dergipark. org.tr/tr/pub/page/about

Devran, Y. ve Elitaş, T. (2017). Uzaktan eğitim: Fırsatlar ve tehditler. AJIT-e: Bilişim Teknolojileri Online Dergisi, 8(27), 31-40. https://doi.org/10.5824/1309-1581.2017.2.003.x

Duman, S . (2020). Salgın döneminde gerçekleştirilen uzaktan eğitim sürecinin değerlendirilmesi. Milli Eğitim Dergisi, Salgın Sürecinde Türkiye'de Ve Dünyada Eğitim, 95-112 . https://doi. org/10.37669/milliegitim.768887

Durak, G., Çankaya, S. ve İzmirli, S. (2020). COVID-19 pandemi döneminde Türkiye'deki üniversitelerin uzaktan eğitim sistemlerinin incelenmesi. Necatibey Eğitim Fakültesi Elektronik Fen ve Matematik Eğitimi Dergisi, 14(1), 787-809. https://doi.org/10.17522/balikesirnef.743080 
Durnalı, M. ve Koşar, D. (2019). Bir uzaktan eğitim merkezinin örgütsel amaçlarının analizi: Bir devlet üniversitesi örneği. Balıkesir Üniversitesi Sosyal Bilimler Enstitüsü Dergisi, 22(42), 85-110. https://doi.org/10.31795/baunsobed.658802

Eken, Ö , Tosun, N, Tuzcu Eken, D . (2020). Covıd-19 salgını ile acil ve zorunlu uzaktan eğitime geçiş: genel bir değerlendirme . Milli Eğitim Dergisi, Salgın Sürecinde Türkiye’de Ve Dünyada Eğitim, 113-128 . https://doi.org/10.37669/milliegitim.780722

Emmerson, A. M. (2004). A history of the changes in practices of distance education in the United States from 1852-2003. New York: Dowling College.

Gökmen, Ö. F., Uysal, M., Yasar, H., Kırksekiz, A., Güvendi, G. M. ve Horzum, M. B. (2017). Türkiye'de 2005-2014 yılları arasında yayınlanan uzaktan eğitim tezlerindeki yöntemsel eğilimler: Bir içerik analizi. Egitim ve Bilim, 42(189). https:// doi.org/10.15390/EB.2017.6163

Gümüş, H., Kavanoz, S. ve Yılmaz, M. B. (2017). Kavram karikatürlerinin mobil öğrenme ortamında ulaştırılmasının ortaöğretimde İngilizce deyim öğrenmeye etkisi. Yüzüncü Yıl Üniversitesi Eğitim Fakültesi Dergisi, 14(1), 815-855. https:// doi.org/10.23891/efdyyu.2017.31

Günay, R. ve Aydın, H. (2015). Türkiye'de çokkültürlü eğitim ile ilgili yapılan araştırmalarda eğilim: bir içerik analizi çalışması. Eğitim ve Bilim, 40(178). https://doi.org/10.15390/EB.2015.3294

Gür Erdoğan, D . (2020). Research trends in studies on lifelong learning: A bibliometric analysis with visual mapping technique (2016-2020) . Sakarya University Journal of Education, 10 (3) , 643-666. https://doi.org/10.19126/suje.819383

İnan, H . (2020). Covid-19 pandemi sürecinde okul öncesi eğitimin yeniden yapılandırılması. Milli Eğitim Dergisi, Salgın Sürecinde Türkiye'de Ve Dünyada Eğitim, 831-849. https:// doi.org/10.37669/milliegitim.754307

İşman, A. (2005). Uzaktan eğitim. Ankara: Öğreti Yayınları.

Karyağdı, N. G. (2020). Covid-19 salgın döneminde muhasebe ve finans grubu dersleri veren akademisyenlerin uzaktan eğitimde yaşadığ 1 sorunların incelenmesi: BEU örneği. Uluslararası Sosyal Bilimler Akademi Dergisi, (4), 1253-1275. https://doi. org/10.47994/usbad.832597

Kaya, Z. (2002). Uzaktan eğitim. Pegem A Yayıncılık.

Kentnor, H. E. (2015). Distance education and the evolution of online learning in the United States. Curriculum and teaching dialogue, 17(1), 21-34. Retrieved from https://digitalcommons. du.edu/cgi/viewcontent.cgi?article $=1026 \&$ context=law_facpub

Keskin, U. ve Akyildiz, M. (2017). Discussion on the applicability of the briefing method on open and distance learning: Animated and scenarian expression applications. Research Journal of Business and Management, 4(1), 71-83. https://doi. org/10.17261/Pressacademia.2017.372

Kılınc, B. K., Yazıc1, B., Gunsoy, B. ve Gunsoy, G. (2020). Perceptions and opinions of graduates about the effects of open and distance learning in Turkey. Turkish Online Journal of Distance Education, 21(1), 121-132. https://doi.org/10.17718/tojde.690369

Koenig, A. E. ve Hill, R. B. (1967). The farther vision: Educational television today. Madison, WI: The University of Wisconsin Press

Korkman, H. and Çolak, T.S. (2021). Investigation of the relationship between Covid-19 fear and intolerance of uncertainty and generalized anxiety disorder. International Online Journal of Education and Teaching (IOJET), 8(1). 418-431.
Kurt, A ve Erdoğan, M. (2015). Program değerlendirme araştırmalarının içerik analizi ve eğilimleri; 2004-2013 yılları arası. Eğitim ve Bilim, 40(178), 199-224. https://doi. org/10.15390/EB.2015.4167

Kurt, A. ve Kurtoğlu Erden, M . (2020). Koronavirüs hastalığ1 2019 sürecinde özel gereksinimli bireyler. Milli Eğitim Dergisi, Salgın Sürecinde Türkiye'de Ve Dünyada Eğitim, 1105-1119. https://doi.org/10.37669/milliegitim.787606

Mphahlele, R. S. S. ve Makokotlela, M. V. (2020). Discourse on student participation in the open distance learning using open educational resources. Journal of Educational Technology and Online Learning, 3(1), 49-68. https://doi.org/10.31681/ jetol.658130

Ozan, C. ve Köse, E. (2014). Eğitim programları ve öğretim alanındaki araştırma eğilimleri. Sakarya University Journal of Education, 4(1), 116-136. Retrieved from https://dergipark. org.tr/tr/pub/suje/issue/20635/220033

Özdoğan, A. ve Berkant, H . (2020). Covid-19 pandemi dönemindeki uzaktan eğitime ilişkin paydaş görüşlerinin incelenmesi . Milli Eğitim Dergisi , Salgın Sürecinde Türkiye'de ve Dünyada Eğitim , 13-43 . https://doi.org/10.37669/milliegitim.788118

Özkök, G. A. ve Bulutlu, Ö. (2020). Examination of intention to use synchronous e-classroom environments of university students in distance education programs. Çukurova Üniversitesi Eğitim Fakültesi Dergisi, 49(2), 895-937. https://doi.org/10.14812/ cufej.755147

Öztürk, M. (2017). Uluslararası̈ŏğrenenlerin akademikgereksinimleri ve uzaktan eğitim. Açıköğretim Uygulamaları ve Araştırmaları Dergisi, 3(2), 140-163. Retrieved from https://dergipark.org.tr/ tr/pub/auad/issue/34117/378450

Parvin, I. (2017). A conceptual framework of virtual interactive teacher training through Open and distance learning for the remote areas English teachers of Bangladesh. Turkish Online Journal of Distance Education, 18(1), 157-165. https://doi. org/10.17718/tojde. 285813

Polat Hopcan, E., Yahşi冈, Ö. ve Hopcan, S. (2020). Technology leadership in educational organizations: A systematic analysis. Öğretim Teknolojisi ve Hayat Boyu Öğrenme Dergisi, 1 (2), 203-220. Retrieved from https://dergipark.org.tr/tr/pub/itall/ issue/56986/816840

Ramdass, K. ve 囚emavhola, F. (2018). Quality practices: An open distance learning perspective. Turkish Online Journal of Distance Education, 19(1), 234-246. https://doi.org/10.17718/ tojde. 382806

Sener, J. (2012). The seven futures of American education: Improving learning and teaching in a screen captured world. North Charleston, SC: CreateSpace

Simonson, M. ve Schlosser, L. A. (2009). Distance Education 3rd Edition: Definition and glossary of terms. IAP.

Tabak, S. (2019). Türkiye' de” gerçekçi matematik eğitimi” ne ilişkin araştırma eğilimleri: Tematik içerik analizi çalışması. Ahi Evran Üniversitesi Kırşehir Eğitim Fakültesi Dergisi, 20(2). https://doi.org/10.29299/kefad.2019.20.02.001

Thomas, D. (2018). Technology in mathematics and science distance education: Automated textual analysis of articles and proceedings papers using Leximancer. The Eurasia Proceedings of Educational and Social Sciences, 9, 28-35. Retrieved from https://dergipark.org.tr/en/pub/epess/issue/38900/454478 
Utami, S., Winarni, I., Handayani, S. K. ve Zuhairi, F. R. (2020). When and who dropouts from distance education?. Turkish Online Journal of Distance Education, 21(2), 141-152. https:// doi.org/10.17718/tojde.728142

Yıldırım, A. ve Şimşek, H. (2013). Sosyal bilimlerde nitel araştırma yöntemleri (9 b.). Ankara: Seçkin.

Yıldız, S. ve Bektaş, F . (2020). Eba tv'de yayınlanan beden eğitimi etkinliklerinin veli ve beden eğitimi öğretmenlerinin görüşleriyle değerlendirilmesi. Milli Eğitim Dergisi, Salgın Sürecinde Türkiye'de Ve Dünyada Eğitim, 969-987 . https:// doi.org/10.37669/milliegitim.773737

Zawacki-Richter, O. (2009). Research areas in distance education: A delphi study. International Review of Research in Open and Distance Learning, 10(3), 1-17. https://doi.org/10.19173/ irrodl.v10i3.674
Zawacki-Richter, O., Backer, E. M. ve Vogt, S. (2009). Review of distance education research (2000 to 2008): Analysis of research areas, methods, and authorship patterns. The International Review of Research in Open and Distributed Learning, 10(6), 21-50. https://doi.org/10.19173/irrodl.v10i6.741

Zawacki-Richter, O., Alturki, U. ve Aldraiweesh, A. (2017). Review and content analysis of the international review of research in open and distance/distributed learning (2000-2015). International Review of Research in Open and Distributed Learning, 18 (2), 1-26. https://doi.org/10.19173/irrodl. v18i2.2806

Zengin, M., Şengel, E. ve Özdemir, M. A. (2018). Eğitimde mobil öğrenme üzerine araştırma eğilimleri: Türkiye örneği. Journal of Instructional Technologies \& Teacher Education, 7(1), 18-35. 


\section{Appendix 1}

\section{UZAKTAN EĞITIM MAKALE INCELEME FORMU (UEMIF)}

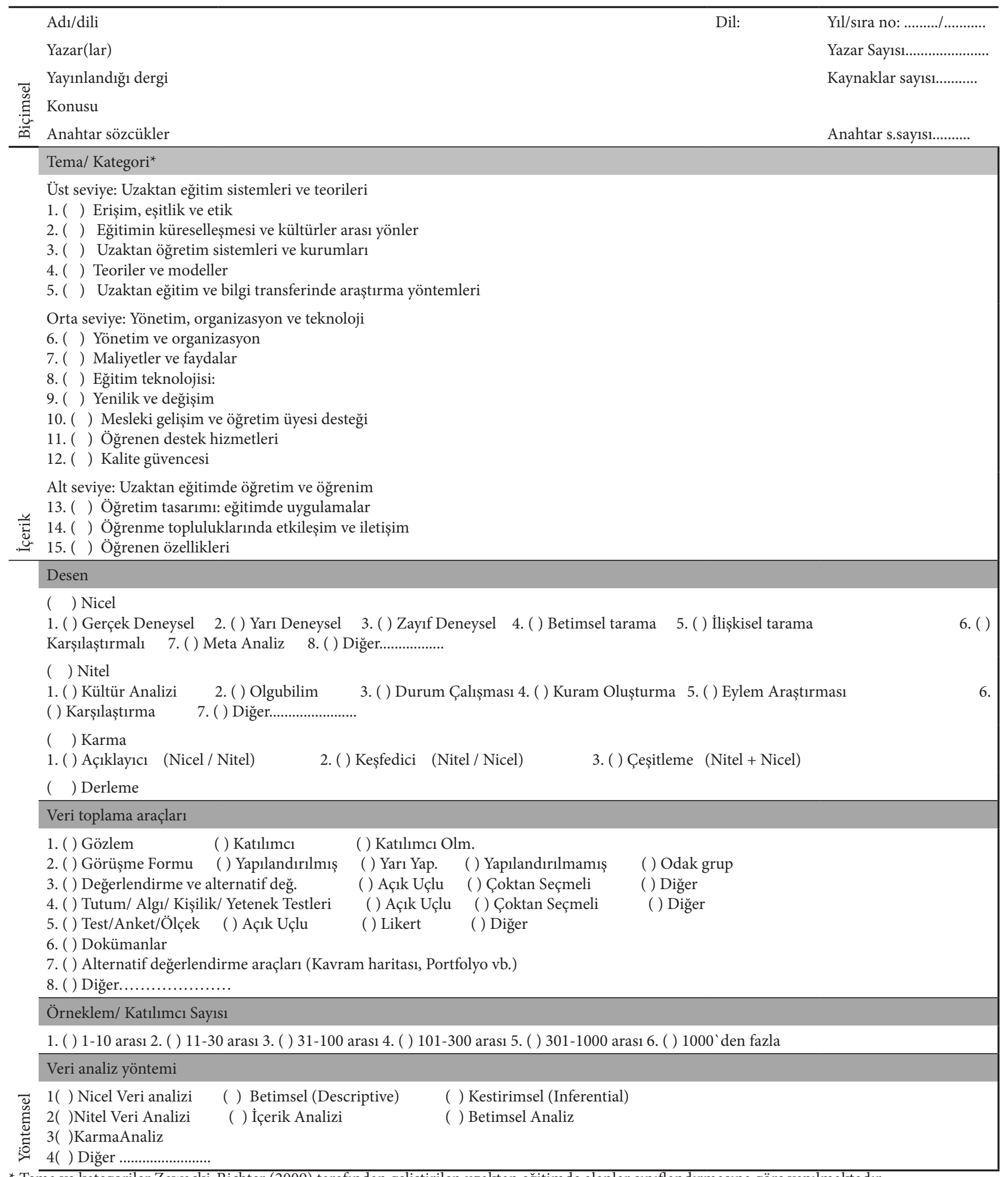

* Tema ve kategoriler Zawacki-Richter (2009) tarafından geliştirilen uzaktan eğitimde alanlar sınıflandırmasına göre yapılmaktadır. 